\title{
Geleneksel Diyarbakır Örgü Peynirinin Tekstürel Özellikleri ve Mikrobiyal Florasının Depolama Periyodu Boyunca Değişimi
}

\author{
Abdulkerim HATíPOĞLU*1@, Șerafettin ÇELİK²® \\ ${ }^{1}$ Mardin Artuklu Üniversitesi, Sağllk Bilimleri Fakültesi, Beslenme ve Diyetetik Bölümü, 47000, Mardin, Türkiye \\ ${ }^{2}$ Harran Üniversitesi, Mühendislik Fakültesi, Gıda Mühendisliği Bölümü, 63050, Şanlıurfa, Türkiye
}

(Alınış / Received: 07.03.2020, Kabul / Accepted: 24.10.2020, Online Yayınlanma / Published Online: 20.12.2020)

\begin{abstract}
Anahtar Kelimeler Diyarbakır Örgü peyniri, Tekstürel özellikler, Mikrobiyal flora, Pasta-filata peynirler
\end{abstract}

Özet: Bu çalışmada, Karacadağ havzasında Diyarbakır Örgü peynirinin üretildiği küçük ölçekli 8 adet süt işletmesinden 2013 yılında alınan toplam 32 adet peynir örneği, $6 \pm 1^{\circ} \mathrm{C}^{\prime}$ de 120 gün süreyle depolanmıștır. Depolama periyodu boyunca 30 gün aralıkla peynirin tekstürel özellikleri ile mikrobiyal florasının değişimi araştırılmıştır. Depolama periyodu boyunca Diyarbakır Örgü peynirinde sertlik $(\mathrm{N})$, yapışkanlık (N.s), elastikiyet $(\mathrm{cm})$, bağlayıcılık, sakızımsılık (N) ve çiğnenebilirlik (mJ) değerlerinde önemli düzeyde azalma tespit edilmiştir $(\mathrm{P}<0.01)$. Başka bir ifadeyle, taze peynir sert ve elastik olmasına rağmen, olgun peynirin ise yumuşadığı, elastikiyetinin azaldığı, yapışkan ve daha kolay çiğnenebilir olduğu sonucuna varılmıștır. Mikrobiyolojik veriler bağlamında, taze peynirin tüketici sağlığı açısından ciddi enfeksiyonel risk oluşturduğu, ancak gida güvenliği ve tüketici sağlığı açısından depolama periyodunun 60. gününde riskin minimize olduğu ve tüketime sunulabileceği sonucuna varılmıștır.

\section{Evaluation of the Textural Properties and Microbial Flora of Traditional Diyarbakır Örgü Cheese During the Ripening Period}

\section{Keywords}

Diyarbakır Örgü cheese,

Textural properties,

Microbial flora,

Pasta-filata cheeses

\begin{abstract}
In this study, a total of 32 cheese samples taken in 2013 from 8 smallscale dairy farms where Diyarbakır Örgü cheese was produced in the Karacadağ region were stored at $6 \pm 1^{\circ} \mathrm{C}$ for 120 days. During the storage period, the changes in textural properties and microbial flora of the cheese were investigated. A significant decrease in the hardness $(\mathrm{N})$, adhesiveness $(\mathrm{Ns})$, springiness $(\mathrm{cm})$, cohesiveness, gumminess $(\mathrm{N})$ and chewiness $(\mathrm{mJ})$ values of the cheese were determined along during the storage period. In other words, although fresh cheese is hard and elastic, it is concluded that mature cheese is softened, its elasticity decreases, it is sticky and easily chewable. In the context of unwanted contaminants, it was concluded that fresh cheese poses a serious infectious risk for consumer health, but the risk is minimized and can be offered for consumption on the 60th day of the storage period with regard to food safety and can be consumer health.
\end{abstract}

\section{Giriş}

Dünyada üretim yöntemi, bileşim ve görünüşü bakımından farklılı arz eden 1000' den fazla peynir çeşidinin olduğu bildirilmektedir [1]. Bu peynir çeşitlerinden pasta-filata tipi peynirler, fermente telemenin sıcak suda haşlanması ve yoğrulması sonucu elde edilmektedirler [2]. Üretim tekniği açısından pasta-filata tipi peynirlerden olan geleneksel Diyarbakır Örgü peyniri (DÖP) de fermente telemesi yüksek sıcaklıkta hașlanan, tipik saç örgüsü şeklinde ve kolayca liflere ayrlabilen, yarım yağlı ve sert bir peynirdir. Bu peynir taze olarak veya salamurada olgunlaştırılarak tüketime arzedilmektedir $[3,57]$.

Geleneksel DÖP, Diyarbakır ilinin güneybatısında yer alan Karacadağ Havzasında ilkbahar aylarında yoğun bir şekilde üretilmektedir. Söz konusu havzada tarıma elverişli alanların az olması, buna karşın geniş çayır-mera alanlarının varlığı nedeniyle koyunculuk başta olmak üzere, yaygın bir şekilde hayvancılık yapılmaktadır [3]. Bu havzada Nisan-Temmuz döneminde üretilen koyun sütü, küçük ölçekli süt 
işletmelerinde çoğunlukla DÖP'ne işlenmektedir. 2012 yılı itibariyle 200 civarında küçük aile işletmesi ve mandırada yaklaşık 8400 ton DÖP' nin üretildiği bildirilmiștir [4]. Havzadaki koyun, keçi ve inek popülasyonları ile birlikte süt üretimi verilerindeki artış dikkate alındığında, bu sayının iyimser bir tahminle bugün için 20 bin tonu aştığ söylenebilir [5].

Üretimdeki artışa paralel bir şekilde ülke sathında tüketimi de sürekli artan DÖP' ün belirli standartlar altında üretiminin yapılması büyük önem arzetmektedir. Bu bağlamda yapılan literatür araştırmasında, bugüne kadar DÖP'nin tekstürel özellikleri ile ilgili yapılmış herhangi bir çalışmaya rastlanılmamıştır. Bilindiği gibi peynirin olgunlaşması sırasında, enzimatik aktivitenin etkisiyle meydana gelen biyokimyasal reaksiyonlar sonucu, peynir tekstüründe önemli değişimler ortaya çıkmaktadır [6]. Tekstür ise, gıdaların mekanik, yapısal ve yüzey özelliklerinin, işitme, dokunma, görme ve kinestetik yolla belirlendiği bir kalite kriteridir [7, 8]. Tekstür organoleptik yollarla subjektif olarak veya bazı ekipmanlar yardımıyla objektif olarak tespit edilebilmektedir [9-11]. Diğer taraftan DÖP' nin üretim bölgesinde olmak üzere, bu peynirin mikrobiyotası ile ilgili de her hangi bir çalışma ortaya konmamıştır. DÖP gibi çiğ sütten yapılan peynirlerde mikrobiyal çeşitliliğin yüksek olduğu bilinmektedir [12]. Fakat bu peynirlerin üretiminde, haşlama sonrası ve depolama aşamalarında yetersiz hijyen uygulamaları nedeniyle patojen bakterilerin varlığı, tüketici sağlığı açısından risk teşkil etmektedir. Ayrıca peynirin olgunlaşması aşamasında tat-aroma maddelerinin sentezlenmesinde, özellikle laktik asit bakterilerinin varlığı ve metabolik aktiviteleri diğer önemli bir husustur.

Geleneksel DÖP'nde piyasa araştırması nitelidiğindeki mikrobiyota çalışmaları ile endüstriyel Örgü peynirinin mikrobiyotası üzerine yapılan sınırlı sayıdaki çalışmanın özeti şöyledir: Geleneksel DÖP'nin mikrobiyal florası ile ilgili yapılan bir çalışmada, peynir florasında ortalama laktik asit bakteri sayısı $1.7 \times 10^{6} \mathrm{kob} / \mathrm{g}$, koliform grubu bakteri sayısı $3.7 \times 10^{2} \mathrm{kob} / \mathrm{g}$ ve maya-küf sayısı ise $1.0 \times 10^{5}$ $\mathrm{kob} / \mathrm{g}$ olarak bildirilmiştir [13]. Başka bir çalışmada ise, DÖP' nde Lactobacillus spp., Lactococcus spp., koliform bakteri sayları ile $E$. coli, küf ve maya

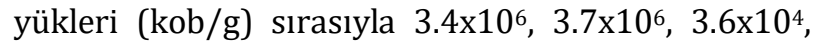
$5 \times 10^{3}, 2.2 \times 10^{3}, 3.1 \times 10^{4}$ olarak bildirilmiştir [14]. Aksu ve ark. (1999)' nın DÖP' nin mikrobiyotası ile ilgili yaptıkları çalışmada ise, koliform bakteri sayısı $3.2 \times 10^{2} \mathrm{kob} / \mathrm{g}$, E. coli sayıs $4.3 \times 10^{1} \mathrm{kob} / \mathrm{g}$ ve mayaküf sayısı 4.9×104 kob/g olarak rapor edilmiştir [15]. Endüstriyel Örgü peynirinin mikrobiyotasının araștırıldığı bir çalıșmada, laktik asit bakterileri, koliform ve maya-küf sayılarının sırasıyla 6.78, 3.73 ve $5.45 \log \mathrm{kob} / \mathrm{g}$ olduğu ifade edilmiştir [16]. Aynı şekilde endüstriyel Örgü peyniri ile ilgili yapılan başka bir çalışmada ise, Lactobacillus spp., koliform grubu bakteri ile maya-küf sayıları sırasıyla $1 \times 10^{8}$, $5 \times 10^{4}$ ve $4.1 \times 10^{5} \mathrm{kob} / \mathrm{g}$ olarak bildirilmiștir [17].

Daha önce de ifade edildiği gibi, şimdiye kadar DÖP'nin tekstürel özellikleri ile ilgili herhangi bir çalışma ortaya konmamıştır. Bir diğer ifade ile bu çalışma, söz konusu peynirin tekstürel özellikleri ile ilgili yapılan ilk çalışma özelliğini taşımaktadır. Aynı şekilde bu çalışma, üretim bölgesinde direkt süt işletmelerinden alınan söz konusu peynirin mikrobiyotasını araştırmak için yapılan ilk çalışmadır. Bu çalışmada geleneksel DÖP'nin tekstürel ve mikrobiyolojik özelliklerinin tespit edilerek Türk Gıda Kodeksi ile Dil Peyniri Standardı bağlamında değerlendirilmesi amaçlanmıștır.

\section{Materyal ve Metot}

Diyarbakır ili Karacadağ Havzası'nda 8 adet küçük ölçekli süt işletmesinden 2013 yılı üretim sezonunda Nisan ayında 1, Mayıs ayında 3 defa olmak üzere toplam 4 defa peynir örneği alınmış ( $n=32), 6 \pm 1^{\circ} C^{\prime}$ de ve salamurada (geleneksel muhafaza yöntemi) 120 gün süreyle depolanmıştır.

\subsection{Tekstürel analizler}

DÖP örneklerinin tekstürel analizleri için TA.XT2 Plus Texture Analyzer (Stable Micro Systems Ltd., Surrey, UK) cihazı kullanılmıştır. Peynir örnekleri $2 \mathrm{~cm}^{3}$ olacak şekilde dilimlenmiştir. Analizler için silindirik alüminyum prop $(\mathrm{P} / 50,50 \mathrm{~mm}$ çap, Stable Micro Systems Ltd., Surrey, UK) kullanılmıştır. Çalışmada \%80 sıkıştırma ile çalışılmış, prob hızı ise test öncesi $1 \mathrm{~mm} / \mathrm{s}$ ve test anındaki hızı $5 \mathrm{~mm} / \mathrm{s}$ olacak şekilde ayarlanmıştır. Test öncesi peynir örnekleri $25{ }^{\circ} \mathrm{C}$ 'de 30 dakika depolanmış ve aynı sıcaklıkta analizler gerçekleştirilmiştir. Peynir örneklerinde sertlik (hardness), yapışkanlık (adhesiveness), elastikiyet (springiness), bağlayıcılık (cohesiveness), sakızımsılık (gumminess) ve çiğnenebilirlik (chewiness) analizleri yapılmıştır. Tekstür analizleri depolama periyodunun 1., 30., 60., 90. ve 120. günlerinde yapılmıştır.

\subsection{Mikrobiyolojik analizler}

DÖP örneklerinde laktik asit bakterileri ile istenmeyen kontaminatların (koliform grubu bakteriler, fekal koliform grubu bakteriler, E.coli ve maya-küf) varlığı ve yükleri depolama periyodunun 1., 15., 30., 60., 90. ve 120. günlerinde araştırılmıștır.

Örnek hazırlama: Geleneksel DÖP örneği (10 g), ilk dilüsyon hazırlamak için $\left(10^{-1}\right)$ içinde $90 \mathrm{~mL}$ steril $\% 2\left(\mathrm{w} / \mathrm{v}\right.$ ) sodyum sitrat bulunan (yaklaşık $45^{\circ} \mathrm{C}$ 'de) steril stomacher torbasına aktarlarak homojenize edilmiştir. Daha sonra steril peptonlu su kullanılarak uygun dilüsyonlar hazırlanmıştır. 
Laktik asit bakteri sayımı: Laktik asit bakteri sayımında, MRS ve M17 agar besiyerleri kullanılmıștır. Lactobacillus cinsi bakteriler için, MRS agar besiyerine $\left(37^{\circ} \mathrm{C}\right.$ 'de 48 saat), kok şekilli laktik asit bakterileri için ise M17 agar $\left(37^{\circ} \mathrm{C}\right.$ 'de 48 saat) besiyerine dökme plak yöntemiyle ekim yapılmış ve anaerobik şartlarda inkübasyona bırakılmıştır [18, 19].

İstenmeyen kontaminant varlı̆̆ı ve yükü: Koliform ve fekal koliform grubu bakterilerin sayımı amacıyla VRBA besiyerine ekim yapılmıștır. Koliform grubu için $30{ }^{\circ} \mathrm{C}$ 'de 24 saat, fekal koliform grubu için ise 44 ${ }^{0} \mathrm{C}^{\prime}$ de 24 saat inkübasyon normu uygulanmıştır. Maya-küf sayımları için, asitliği tartarik asitle (\%10' luk, $14 \mathrm{~mL} / \mathrm{L}$ ) asitliği $\mathrm{pH} 3.5^{\prime} \mathrm{e}$ ayarlanan PDA besiyerine ekim yapılmış ve petriler $25^{\circ} \mathrm{C}^{\prime}$ de 5 gün inkübasyona bırakılmıștır $[17,18]$. E. coli varlığı ve sayımı için Chromocult TBX agar besiyerine dökme plak yöntemiyle ekim yapılarak, $44{ }^{\circ} \mathrm{C}$ 'de 24 saat inkübe edilmiștir. İnkübasyon sonrası, petrilerde direk koloni sayımı yapılmıştır.

\section{3. İstatistiksel değerlendirme}

Çalışmaya ait veriler tek yönlü ANOVA ile analiz edilmiş (MINITAB $\AA$ 16.1), önemli bulunan ortalamalar arasındaki farklılık Tukey çoklu karşılaştırma testi ile belirlenmiş̦tir [20]. Analiz öncesi mikrobiyolojik parametrelere ait veriler, logaritmik transformasyona (log kob/g) tabi tutulmuştur.

Tablo 1. Depolama periyodu boyunca geleneksel DöP' inin tekstürel özelliklerine ait ortalama değerler ve oluşan gruplar $\underline{(\mathrm{n}=32)^{*}}$

\begin{tabular}{ccccccc}
\hline DP & Sertlik (N) & $\begin{array}{c}\text { Yapışkanlık } \\
\text { (N.s) }\end{array}$ & $\begin{array}{c}\text { Elastikiyet } \\
\text { (cm) }\end{array}$ & Bağlayıcılık & Sakızımsılık (N) Çiğnenebilirlik (mJ) \\
\hline 1. gün & $11087^{\mathrm{a}}$ & $-0.26^{\mathrm{a}}$ & $0.87^{\mathrm{a}}$ & $0.75^{\mathrm{a}}$ & $8338^{\mathrm{a}}$ & $7248 \mathrm{a}$ \\
30. gün & $9979 \mathrm{~b}$ & $-0.43^{\mathrm{b}}$ & $0.84^{\mathrm{b}}$ & $0.72^{\mathrm{b}}$ & $7150^{\mathrm{b}}$ & $6012^{\mathrm{b}}$ \\
60. gün & $8970^{\mathrm{c}}$ & $-0.55^{\mathrm{c}}$ & $0.83^{\mathrm{b}}$ & $0.70^{\mathrm{bc}}$ & $6272^{\mathrm{c}}$ & $5188^{\mathrm{c}}$ \\
90. gün & $7934^{\mathrm{d}}$ & $-0.71^{\mathrm{d}}$ & $0.81^{\mathrm{c}}$ & $0.68^{\mathrm{c}}$ & $5424 \mathrm{~d}$ & $4375^{\mathrm{d}}$ \\
120. gün & $6852^{\mathrm{e}}$ & $-0.90^{\mathrm{e}}$ & $0.76 \mathrm{~d}$ & $0.65^{\mathrm{d}}$ & $4480^{\mathrm{e}}$ & $3408^{\mathrm{e}}$ \\
Ortalama & 8964 & -0.57 & 0.82 & 0.70 & 6333 & 5246 \\
SS & 566.99 & 0.11 & 0.03 & 0.03 & 619.98 & 620.76 \\
\hline
\end{tabular}

DP: Depolama periyodu; SS: Standart sapma

*Aynı sütunda farklı harflerle gösterilen ortalamalar arasındaki farklılık önemlidir $(\mathrm{P}<0.01)$.

Tablo 2. Depolama periyodu boyunca geleneksel DÖP florasında bazı mikrobiyolojik özelliklerine ait ortalama değerler (log $\mathrm{kob} / \mathrm{g})$

\begin{tabular}{|c|c|c|c|c|c|c|}
\hline \multirow[t]{2}{*}{$\mathrm{kob} / \mathrm{g})$} & \multirow{2}{*}{$\begin{array}{c}\text { ve } \\
\text { Kok şekilli } \\
\text { LAB } \\
\end{array}$} & \multirow[b]{2}{*}{$\begin{array}{c}\text { Basil şekilli } \\
\text { LAB }\end{array}$} & \multirow{2}{*}{$\begin{array}{c}\text { olușan } \\
\begin{array}{c}\text { Koliform grubu } \\
\text { bakteriler }\end{array}\end{array}$} & \multicolumn{2}{|c|}{ gruplar } & \multirow[b]{2}{*}{ Maya-Küf } \\
\hline & & & & $\begin{array}{c}\text { Fekal koliform } \\
\text { grubu bakteriler }\end{array}$ & E. coli & \\
\hline 1. gün & 7.89 a & $7.84 \mathrm{a}$ & $5.55^{\text {a }}$ & $4.64^{\mathrm{a}}$ & $3.57 \mathrm{a}$ & $2.95^{a}$ \\
\hline 15. gün & $7.77 \mathrm{ab}$ & $7.44 \mathrm{~b}$ & 5.09 b & $4.00^{b}$ & $2.50^{b}$ & $2.62 \mathrm{~b}$ \\
\hline 30. gün & $7.77 \mathrm{ab}$ & $7.31^{b}$ & $4.61^{c}$ & $3.56^{c}$ & $1.61^{c}$ & $2.68 \mathrm{ab}$ \\
\hline 60. gün & $7.53 \mathrm{bc}$ & 7.22 b & $3.06^{d}$ & $2.07 \mathrm{~d}$ & $<1.00 \mathrm{~d}$ & $2.45^{b}$ \\
\hline 90. gün & $7.29 \mathrm{~cd}$ & $6.81 \mathrm{c}$ & $<1.00 \mathrm{e}$ & $<1.00 \mathrm{e}$ & $<1.00 \mathrm{~d}$ & $2.48 \mathrm{~b}$ \\
\hline 120. gün & $7.16^{d}$ & $6.92 c$ & $<1.00 \mathrm{e}$ & $<1.00 \mathrm{e}$ & $<1.00 \mathrm{~d}$ & $2.60 \mathrm{~b}$ \\
\hline Ortalama & 7.57 & 7.26 & 3.39 & 2.72 & 1.78 & 2.63 \\
\hline SS & 0.55 & 0.58 & 0.49 & 0.48 & 0.46 & 0.53 \\
\hline
\end{tabular}

DP: Depolama periyodu; SS: Standart sapma

*Aynı sütunda farklı harflerle gösterilen ortalamalar arasındaki farklılık önemlidir $(\mathrm{P}<0.01)$. 
Depolama periyodu boyunca geleneksel DÖP florasında bazı mikrobiyolojik özelliklerine ait ortalama değerler (log kob/g) ve oluşan gruplar, Tablo 2'de verilmiştir.

DÖP florasında, kok şekilli (Lactococcus sp., Enterococcus sp.) bakteri sayıs depolama periyodunun ilk gününde $7.89 \mathrm{log} \mathrm{kob} / \mathrm{g}$ iken periyot boyunca azalmış ve periyodun 120 . gününde 7.16 kob/g düzeyine inmiştir. Benzer bir azalma, peynir florasında basil șekilli (Lactobacillus sp.) bakteri yükünde de görülmektedir. DÖP florasında koliform ve fekal koliform grubu bakteri sayıları periyodun 90 . gününde $<1 \log \mathrm{kob} / \mathrm{g}$ düzeyine inmiștir. Peynir florasında E.coli sayısı ise periyodun 60 . günde $<1 \log$ kob/g seviyesine inmiştir. Söz konusu peynirin florasında maya-küf sayısı, periyodun 1.gününde 2.95 $\log \mathrm{kob} / \mathrm{g}$, bu sayı 60.günde azalmıș ve $2.48 \mathrm{log} \mathrm{kob} / \mathrm{g}$ olarak hesaplanmış; periyodun 90 . ve 120.günlerinde ise nisbi bir artış göstermiş, ancak bu durum istatistiksel olarak önemli bulunmamıştır.

\section{Tartışma ve Sonuç}

\subsection{Tekstürel özellikler}

Olgunlaşma periyodunda oluşan proteoliz düzeyi, tuz oranı ve nem içeriği peynirin sertliğini etkilemektedir [22-25]. Tablo 1'de görüldügü gibi, DÖP' inde sertlik değeri depolama periyodu boyunca önemli düzeyde azalmıştır. Bilindiği gibi sertlik ve nem arasında ters bir ilişki bulunmaktadır $[10,26]$. Bu durum, salamurada olgunlaştırılan DÖP' nde proteoliz ve lipoliz sonucu oluşan parçalanma ürünlerinin daha fazla su tutmalarından kaynaklanmış olabilir. Pastafilata tipi peynir çeșidi olan ve kuru tuzlanan Kaskaval peynirinin sertlik değerlerinin ise depolama süresince arttığı bildirilmiştir [8]. Araştırmacılar bu durumu, depolama periyodu boyunca nem kaybına bağlı olarak, peynirin KM oranının artması sonucu peynir sertliğinin arttığı şeklinde açıklamışlardır.

Salamurada olgunlaştırılan DÖP'nde nem oranının depolama periyodu boyunca arttığı bildirilmiştir (Tablo 3) [3].
Diğer taraftan sertlik ve proteoliz düzeyi arasında da negatif bir korelasyon olduğu; başka bir deyişle, peynirde proteoliz düzeyi arttıkça, sertlik değerlerinde azalma olduğu bildirilmiştir [22]. Peynir tekstüründe yumuşama, olgunlaşma periyodunun başlangıcında pıhtılaştırıcı enzimler ile $\alpha_{\mathrm{s} 1 \text {-kazeinin }}$ phe23-phe24 arasındaki peptid bağının parçalanması ile başlamakta, daha sonra $\alpha_{\mathrm{s} 1}-\mathrm{CN}$ (f24-199) ( $\alpha_{\mathrm{s} 1-\mathrm{I}-}$ kazein) ve diğer kazein miseli bileșenlerinin parçalanması ile devam etmektedir [26]. Bu bağlamda pıhtısı haşlanan peynirlerden Kaşar peyniri $[28,29]$, Caciocavallo Pugliese [30] ve Kefalogravyer peynirlerinde [31] olgunlaşmayla birlikte sertliğin azaldığı; çiğ inek ve manda sütü karıșımından üretilen, pıhtısı haşlanan ve kuru tuzlanan Ras peynirinde [25] ise olgunlaşma ile birlikte sertliğin arttığı bildirilmiştir. Diğer taraftan pıhtısı haşlanan ve vakum ambalajda olgunlaştırılan Oaxaca peynirinde sertlik değerinin, olgunlaşma periyodunun 8. gününe kadar ihmal edilecek düzeyde arttığı, daha sonra periyodun 24. gününe kadar azaldığ $(16.16 \mathrm{~N})$ rapor edilmiştir [32]. Taze Hellim peynirinde sertlik değerinin $7.88 \mathrm{~N}$ olduğu, \%13 tuz içeren salamurada 48 saat depolama sonrası bu değerin 15.46 N'ye yükseldiği bildirilmiștir [33]. Pasta-filata tipi peynir çeşidi olan taze Telita peynirinde sertlik değerinin 20.44 N olduğu bildirilmiștir [34].

Olgun peynirlerde, lipoliz sonucu peynirde yağ oranının azalması ile birlikte yapışkanlık değerinin de azaldığ yapışkanlığın peynirin asitliği, proteoliz düzeyi, protein ve yağ fraksiyonlarının polar karakteristikleri ile ilişkili olduğu bildirilmiştir [36]. DÖP'nin ortalama yapışkanlık değeri taze peynirde -0.26 N.s iken, olgun (120 günlük) peynirde -0.90 N.s olarak tespit edilmiştir (Tablo 1). Üretim prosesi bakımından DÖP ile benzerlik gösteren Telli peynirin 90 günlük olgunlaşma periyodu boyunca yapışkanlık değerinin $\operatorname{arttığ}_{1}[36]$, taze Telita peynirinde ise bu değer, -0.66 N.s olarak bildirilmiştir [33]. Taze (1 günlük) Oaxaca peynirinde bu değer, 12.6 N.s iken, periyodun sonunda (24 günlük) ise bu değer artmış ve 42.7 N.s olmuştur [32].

Tablo 3. Depolama süresince Diyarbakır Örgü Peynirinin bileşim özelliklerine ait ortalama değerler (\%) ve oluşan gruplar $(\mathrm{n}=32)[3]$

\begin{tabular}{cccccccc}
\hline DP (gün) & KM & Protein & Yăg & KM'de Yağ & Kül & Tuz & KM'de Tuz \\
\hline $\mathbf{1}$ & $55.44^{\mathrm{a}}$ & $26.56^{\mathrm{a}}$ & $21.56^{\mathrm{a}}$ & $38.84^{\mathrm{a}}$ & $7.31^{\mathrm{c}}$ & $6.31^{\mathrm{c}}$ & $11.40^{\mathrm{e}}$ \\
$\mathbf{3 0}$ & $55.32^{\mathrm{a}}$ & $25.84^{\mathrm{b}}$ & $20.71^{\mathrm{b}}$ & $37.38^{\mathrm{bc}}$ & $8.77^{\mathrm{b}}$ & $7.70^{\mathrm{b}}$ & $13.95^{\mathrm{d}}$ \\
$\mathbf{6 0}$ & $54.7^{\mathrm{a}}$ & $25.23^{\mathrm{c}}$ & $20.33^{\mathrm{bc}}$ & $37.07^{\mathrm{c}}$ & $9.19^{\mathrm{a}}$ & $8.04^{\mathrm{a}}$ & $14.72^{\mathrm{c}}$ \\
$\mathbf{9 0}$ & $53.78^{\mathrm{b}}$ & $24.36^{\mathrm{d}}$ & $20.19^{\mathrm{bc}}$ & $37.47^{\mathrm{bc}}$ & $9.22^{\mathrm{a}}$ & $8.11^{\mathrm{a}}$ & $15.09^{\mathrm{b}}$ \\
$\mathbf{1 2 0}$ & $52.84^{\mathrm{c}}$ & $23.47^{\mathrm{e}}$ & $20.06^{\mathrm{c}}$ & $37.88^{\mathrm{b}}$ & $9.32^{\mathrm{a}}$ & $8.16^{\mathrm{a}}$ & $15.48^{\mathrm{a}}$ \\
$\mathbf{0 r t .}$ & 54.43 & 25.20 & 20.57 & 37.73 & 8.77 & 7.67 & 14.13 \\
$\mathbf{S S}$ & 1.13 & $0.64^{2}$ & 0.80 & 0.99 & 0.33 & 0.27 & 0.52 \\
\hline
\end{tabular}

DP: Depolama periyodu; SS: Standard sapma; KM: Kurumadde

*Aynı sütunda farklı harflerle gösterilen ortalamalar arasındaki farklılık önemlidir ( $\mathrm{P}<0.01)$.

Taze peynirlerin olgun olanlara göre daha elastik daha fazla yağ içermesinden kaynaklandığı [37], olduğu, bu durumun da muhtemelen taze peynirlerin ayrıca elastikiyet ile yapışkanlık, bağlayıcılık ve 
çiğnenebilirlik değerleri arasında pozitif bir korelasyon olduğu bildirilmiştir [38]. DÖP' inde elastikiyet değeri, 120 günlük depolama periyodu boyunca önemli düzeyde azalmıştır (Tablo 1). Tel peynirinde olgunlaşma periyodunun 30 . gününde elastikiyet değerinin arttığı, periyodun 90. gününe kadar ise bu değerin sabit kaldığı bildirilmiştir [36]. Kaşar peynirinde, depolama periyodunun 45 . gününe kadar elastikiyet değerinin istatistiksel olarak sabit kaldığı, depolama periyodunun 90. gününe kadar bu değerin azaldığı bildirilmiştir [29]. Oaxaca peynirinin elastikiyet değeri, depolama periyodunun 8. gününe kadar istatistiksel olarak önemli bir değișikliğin olmadığı (0.80-0.69 cm), periyodun devam eden günlerinde ise bu değerin azaldığ $(0.64-0.59 \mathrm{~cm})$ ifade edilmiştir [32]. Diğer taraftan çiğ sütten üretilen pasta-filata tipi Ras peynirinin elastikiyet değerinde depolama periyodu boyunca istatistiksel olarak önemli bir değişikliğin olmadığı bildirilmiştir [25].

Olgunlaşma periyodunda lipoliz [35] ve proteoliz düzeylerinin yükselmesi sonucu [39], peynirde bağlayıcılık değerinin azaldığı bildirilmiştir. DÖP' nin ortalama bağlayıcılık değeri, depolama periyodunun 1. gününde 0.75 birim iken, periyot boyunca azalmıș ve 120 . günde 0.65 birim olarak hesaplanmıştır. Kaşar peynirinin bağlayıcılık değerinin, depolama periyodunun 45. gününe kadar istatistiksel olarak değişmediği, takip eden depolama günlerinde ise bu değerin azaldığı bildirilmiştir [29]. Diğer taraftan Tel peynirinde depolama periyodunun 30. gününe kadar bağlayıcılık değerinin arttığı, periyodun geri kalan döneminde ise sürekli olarak azaldığı ifade edilmiștir [36]. Ayrıca, depolama periyodunda çiğ sütten yapılan Ras peynirinde bağlayıcıllk değerinde istatistiksel olarak önemli bir değişikliğin olmadığı bildirilmiştir [25]. Benzer şekilde, 24 günlük depolama süresince Oaxaca peynirinde de bağlayıcılık değerindeki değişimin istatistiki olarak önemli olmadığı belirtilmiştir [32]. Söz konusu durumu destekleyen bir başka araștırmada, \%13 tuz içeren salamurada $4{ }^{\circ} \mathrm{C}$ 'de 48 saat depolanan Hellim peynirinde bağlayıcılık değerinin değişmediği (0.49) tespit edilmiștir [33]. Diğer taraftan, taze Telita peynirinde ortalama bağlayıcılık değerinin 0.6 olduğu bildirilmiştir [34].

Tablo 1'de görüldüğü gibi, DÖP' inde sakızımsılık (gumminess) değerleri, depolama periyodu boyunca önemli düzeyde azalmıştır. 90 günlük depolama periyodu boyunca Kaşar peynirinin sakızımsılık değerinde istatistiksel olarak bir değişikliğin olmadığı [29], Tel peynirde depolama periyodunun 30. gününe kadar sakızımsılık değerinde bir artış, depolamanın takip eden günlerinde ise sürekli azalma olduğu [36], Kefalogravyer peynirinde ise olgunlaşma periyodu boyunca sakızımsılık değerinin azaldığı bildirilmiştir [31].
Beyaz peynire oranla, taze DÖP oldukça uzun sürede çiğnenerek yutmaya hazır hale getirilmektedir. DÖP'nin çiğnenebilirlik değerleri, depolama periyodu boyunca azalma göstermiștir (Tablo 1). Bu durum, periyot boyunca peynirin yumuşamasından kaynaklanmış olabilir [3]. Ras peynirinde 120 günlük depolama periyodu boyunca çiğnenebilirlik değerlerinin arttığı [25], Tel [36] peynirinde ise bu değerin olgunlaşma periyodu boyunca dalgalı bir seyir izlediği bildirilmiştir. Taze Telita peynirinde ise bu değer $8.11 \mathrm{~N}$ olarak rapor edilmiştir [34].

Taze ve olgun DÖP, tekstürel özellikleri açısından önemli düzeyde bir birinden farklıllk arz etmektedir. Bu bağlamda olgun peynire oranla, taze peynirin sert, yapışkan, elastikiyet, bağlayıcıllk, sakızımsılık ve çiğnenebilirlik değerlerinin daha yüksek olduğu tespit edilmiştir. Başka bir ifadeyle, analiz edilen tekstürel özellikler bakımından olgunlaşma periyodu boyunca DÖP'nin yumuşadığı ve tüketime uygun hale geldiği sonucuna varılmıştır. Diğer taraftan sütün bileşimi, peynir üretim prosesi ve peynirin olgunlaşma prosesi de peynir tekstürünün oluşumuna etki etmektedir [21].

\subsection{Mikrobiyolojik parametreler}

DÖP florasında M17 agarda gelișen kok şekilli (Lactococcus spp., Enterococcus spp.) bakteri sayısı, olgunlașma periyodunun 1. gününde $7.89 \mathrm{log} \mathrm{kob} / \mathrm{g}$ iken, periyot boyunca nispi bir azalma göstermiş ve periyodun 120 . gününde $7.16 \mathrm{log} \mathrm{kob} / \mathrm{g}$ değerini ulaşmıștır. $\mathrm{Bu}$ durum, olgunlaşma periyodunun sonuna kadar Lactococcus spp. bakteri sayısının azaldığını bildiren bazı araştırıcıların [40-43] bulgularıyla benzerlik gösterirken, diğer bazı araştırıcıların [44-46] bulgularından farklılık göstermiştir. Peynir florasında kok şekilli bakteri sayısındaki bu farklılık, peynir üretiminde uygulanan teknolojik işlemler ile üretimde kullanılan çiğ sütün mikrobiyal florasının farklı olmasından kaynaklanmış olabilir.

DöP'nin ortalama basil şekilli (Lactobacillus spp.) bakteri sayısı, taze (1 günlük) peynirde 7.84 log kob/g olduğu ve olgunlaşma periyodu boyunca istatistiki olarak önemli düzeyde azaldığı, periyodun 90. gününde bu sayının $6.81 \mathrm{log} \mathrm{kob} / \mathrm{g}$ değerine düştüğü görülmektedir (Tablo 2). Benzer durum, bazı araştırıcılar tarafından Beyaz peynir [42], Roncal peyniri [41] ve Dil peynirinde [46] de rapor edilmiştir. Aksine, salamurada olgunlaştırılan Tulum peyniri ile Zamorano peynirinde, olgunlașma periyodu boyunca Lactobacillus cinsi bakterilerin istatistiki olarak belirli bir süre arttığını bildiren diğer araştırıcıların $[47,48]$ bulgularından farklılık göstermektedir.

DÖP florasında koliform grubu bakteri sayısı, olgunlaşma periyodu boyunca çok önemli düzeyde azaldığı görülmektedir (Tablo 2). Bu bağlamda, DÖP 
florasında olgunlaşma periyodunun 1 . ve 90. günlerinde ortalama koliform grubu bakteri sayıları sırasiyla $5.55 \log \mathrm{kob} / \mathrm{g}$ ve $<1.00 \mathrm{log} \mathrm{kob} / \mathrm{g}$ olarak tespit edilmiștir. Bu çalışmada koliform grubu bakteri sayısı bakımından DÖP'nin taze olarak tüketilmesi tüketici sağlığı açısından enfeksiyonel risk oluşturmakta, ancak olgunlaştırma periyodunun 90 . gününde riskin minimize olduğu anlaşılmaktadır. Üretim prosesi açısından DÖP'ne benzeyen Dil peynirinin en fazla $95 \mathrm{kob} / \mathrm{g}(1.98 \mathrm{log} \mathrm{kob} / \mathrm{g})$ koliform grubu bakteri içerebileceği bildirilmiștir [49]. Koliform grubu bakteri yükü açısından, DöP'nin olgunlaşma periyodunun 90. gününde Dil peyniri Standardına uygun hale geldiği, başka bir deyişle, periyodun 90. gününde gıda güvenliği ve tüketici sağlığı bakımından peynirde riskin minimize olduğu sonucuna varılmıştır. Birçok araştırıcı tarafından koliform grubu bakteri sayısının, olgunlaşma periyodunun ilk gününden itibaren devamlı bir şekilde azalma gösterdiği ve peynir çeşitlerine göre farklı zamanlarda tamamen elemine olduğu bildirilmiştir [45-47, 50, 51]. Dil peynirinin mikrobiyal florası ile ilgili yapılan bir çalışmada, çiğ sütten üretilen peynirde olgunlaşma periyodunun 90 . gününde $2.06 \mathrm{log} \mathrm{kob} / \mathrm{g}$ düzeyinde koliform grubu bakterinin canlı kaldığı, dolayısıyla bu grup bakteriler açısından standarda uygun olmadiğı ve tüketici sağlığı açısından risk taşıdığını bildirilmiştir [46]. Starter kültür kullanılarak pastörize sütten üretilen Keçi peynirinde olgunlaşma periyodunun uzaması ile birlikte koliform grubu bakteri sayısının azaldığı, ayrıca $\mathrm{pH}$ 'nın düşmesi sonucu koliform grubu bakteri sayısının azaldığı, koliform grubu bakteri sayısı ile olgunlaşma süresi arasında negatif ve önemli bir ilişki olduğu bildirilmiștir [52]. Diğer taraftan, olgunlașma periyodu boyunca koliform grubu bakteri sayısındaki azalmanın, periyot boyunca peynirde nem oranında azalma ve tuz oranındaki yükselmeden kaynaklandığı bildirilmiştir [19].

DÖP florasında, fekal koliform grubu bakteri sayısı taze peynirde (1 günlük) $4.64 \mathrm{log} \mathrm{kob} / \mathrm{g}$ iken, depolama periyodu boyunca bu sayı azalmış ve periyodun 90 gününde peynirde $<1 \mathrm{log} \mathrm{kob} / \mathrm{g}$ değerine düşmüştür. Çiğ sütten üretilen Dil peynirinde fekal koliform grubu bakteri sayısı olgunlaşma periyodunun başlangıcında $2.45 \mathrm{log}$ $\mathrm{kob} / \mathrm{g}$, periyodun 90. gününde ise $1.04 \mathrm{log} \mathrm{kob} / \mathrm{g}$ olarak bildirilmiştir [46]. Telemesi haşlanan Montasio peynirinde, fekal koliform grubu bakterilerin depolama periyodunun 30.gününde $<1$ $\log \mathrm{kob} / g$ düzeyine düştüğü [47], çiğ keçi sütünden üretilen Tenerife peynirinde ise olgunlaşma periyodunun 60. gününde fekal koliform grubu bakterilerin sayılamadığı bildirilmiştir [53].

$\mathrm{Bu}$ çalışmada elde edilen verilere göre, taze DÖP florasında ortalama $3.57 \mathrm{log} \mathrm{kob} / \mathrm{g}$ E.coli varlığına karşılık, 4 aylık depolama periyodu boyunca fekal koliform grubu bakteri sayısındaki azalmaya paralel bir şekilde söz konusu bakteri sayısı azalmış ve 60 . günde peynir florasında ortalama E.coli sayısı $<1 \mathrm{log}$ kob/g (<2.54) olarak hesaplanmıștır (Tablo 2). Bu veriler doğrultusunda, olgunlaşma periyodunun 60 . gününde tüketici sağlığı bakımından riskin minimize olduğu ve DÖP' nin tüketime sunulabileceği sonucuna varılmıştır [49, 58]. Ancak, üretim prosesi bakımından geleneksel DÖP ile benzerlik gösteren Dil peynirinin olgunlaşma periyodu boyunca E. coli sayısının azaldığı, periyodun 90. gününde bile bu sayının $<1 \quad \log \mathrm{kob} / \mathrm{g}$ değerine düşmediği bildirilmiştir [46].

DÖP florasında maya-küf sayısı, depolama periyodu boyunca çok önemli düzeyde $(\mathrm{P}<0.01)$ azalma göstermiştir (Tablo 2). Tabloda görüldüğü gibi, DÖP florasında en yüksek ortalama maya-küf sayısı 2.95 $\log \mathrm{kob} / \mathrm{g}$ ile taze peynirde, en düşük maya-küf sayısı ise $2.45 \mathrm{log} \mathrm{kob} / \mathrm{g}$ ile olgunlaşma periyodunun 60 . gününde tespit edilmiș, periyodun 90 . gününden sonra peynirin maya-küf varlığında gözlenen artış istatistiksel olarak önemli bulunmamıştır. Örgü ve Lavaş peynirlerinin mikrobiyolojik parametrelerine ilişskin yapılan farklı çalışmalarda, söz konusu peynirlerin maya-küf yükü 4.69-5.61 log kob/g aralığında bildirilmiştir [13-17, 54].

Dil Peyniri Standardına göre, peynirde maksimum maya sayısı $1 \times 10^{4} \mathrm{kob} / \mathrm{g}$ ve maksimum küf sayısı ise $1 \times 10^{3} \mathrm{kob} / \mathrm{g}$ ile sınırlandırılmıştır [49]. Bu bağlamda çalışmadaki veriler esas alındığında, Dil peyniri ile üretim prosesi bakımından benzerlik gösteren DÖP, olgunlaştırma periyodunun ilk gününden itibaren, maya-küf yükü açısından anılan standarda uygunluk arz etmiştir. Peynir florasında olgunlaşma periyodu boyunca maya-küf sayısının sürekli azalma göstermesi bazı araștırıcıların [42, 45, 46] salamurada olgunlaştırılan Montasio, Beyaz peynir ve Dil peynirindeki bulgularıyla benzerlik göstermekte, olgunlaşma periyodunun belirli günlerine kadar sayıca arttıktan sonra zamanla azaldığını belirten Manolopoulou ve ark. [55]' nın Feta peynirinde tespit ettikleri bulgulardan farklılık arz etmektedir. Peynir florasında olgunlaşma periyodunun sonuna kadar maya-küf varlı̆ı tespit edilmesi, bu mikroorganizmaların geniş bir su aktivitesi aralığında (aw: 0.65-0.90), düşük pH (bazı durumlarda $\mathrm{pH}$ 3' ün altında) ve düşük sıcaklıkta gelişebilme yeteneklerine bağlanabilir [56].

Pasta-filata tipi bir peynir çeşidi olan DÖP florasında, depolama periyodunun başlangıcında koliform, fekal koliform, E. coli ve maya-küf gibi istenmeyen kontaminant yüklerinin yüksek olduğu görülmektedir. Bu durum, üretim ve depolama aşamalarında hijyen ve sanitasyon kurallarına gereken özenin gösterilmemesinden kaynaklandığı ifade edilebilir. DÖP florasında olgunlaşma periyodunun 60. gününde E.coli, periyodun 90. gününde ise koliform ve fekal koliform grubu 
bakterilere ait koloniler tespit edilememiştir. Ayrıca, peynirde koliform grubu bakteri yükü Türk Gıda Kodeksi Fermente Süt Ürünleri Tebliği ile Dil Peyniri Standardında izin verilen $10^{3} \mathrm{kob} / \mathrm{g}$ düzeyine düşmüştür $[49,58]$. Bu durum, DÖP' nin olgunlaşma periyodunun 60. gününde tüketici sağlığı bakımından riskin minimize olduğu ve güvenilirlik kazandığını ifade etmektedir.

Geleneksel yöntemlerle üretilen taze DÖP' nin sert ve elastik olduğu, olgunlaşma periyodu boyunca yumuşayarak elastikiyetinin azaldığı, olgun peynirin ise daha yapışkan, ancak daha kolay çiğnenebildiği söylenebilir. Bu durum, depolama periyodu boyunca peynir matriksinde lipolitik ve proteolitik parçalanmalar sonucu ve peynirdeki nem değerinin artmasından kaynaklanmıştır.

Türk Gıda Kodeksi Peynir Tebliği'nde, peynir mayası ile elde edilen telemenin fermantasyonu sonrasinda tuzlu/tuzsuz sıcak su içerisinde veya sıcak peyniraltı suyunda haşlanması sonucu üretilen Örgü peyniri, Dil peyniri, Abaza peyniri ve Kaşar peyniri gibi peynirlerin taze olarak tüketime arz edilebileceği belirtilmiștir [57]. Ancak üretim ve depolama aşamalarında hijyenik kurallara yeterince uyulmaması nedeniyle, DÖP' nin florasında depolama periyodunun 60. gününde koliform, fekal koliform ve E. coli yükünün yüksek olması ve bu hali ile tüketime sunulamaması tüketici sağlığı bakımından önem taşımaktadır. $\mathrm{Bu}$ bağlamda, DÖP üretim prosesinde, haşlama sonrası teleme hamurunun yoğrulması, gramajlama sonrası hamurun ip şeklinde uzatılarak tipik saç örgüsü şeklinde örülmesi aşamaları ile salamura hazırlama ve muhafaza edilmesinde yoğun işçiliğe ihtiyaç duyulmaktadır. Söz konusu üretim aşamalarında, özellikle çalışanların, kişisel bakımları ile ekipmanların kullanımında hijyen ve sanitasyon kurallarına uymadıklarını göstermektedir.

\section{Teşekkür}

$\mathrm{Bu}$ çalışma, Harran Üniversitesi Bilimsel Araştırma Projeleri Koordinatörlüğü (HÜBAK Proje No: 12019) tarafından desteklenmiştir.

\section{Etik Beyanı/Declaration of Ethical Code}

Bu çalışmada, "Yükseköğretim Kurumları Bilimsel Araştırma ve Yayın Etiği Yönergesi" kapsamında uyulması gerekli tüm kurallara uyulduğunu, bahsi geçen yönergenin "Bilimsel Araştırma ve Yayın Etiğine Aykırı Eylemler" başlı̆̆ı altında belirtilen eylemlerden hiçbirinin gerçekleştirilmediğini taahhüt ederiz.

\section{Kaynakça}

[1] McSweeney, P. L. H., Ottogalli, G., Fox, P. F., 2004. Diversity of cheese varieties: An overview. In Cheese: Chemistry, physics and microbiology.
Volume 2, ss 1-23. London, UK: Elsevier Applied Science. 434s.

[2] Pappa, E. C., Kondyli, E., Samelis, J., 2019. Microbiological and biochemical characteristics of Kashkaval cheese produced using pasteurised or raw milk. International Dairy Journal, 89, 6067.

[3] Hatipoglu, A., Celik, S., 2020. The compositional and biochemical characteristics of traditional Diyarbakir Örgü cheese during the ripening period. Indian Journal of Dairy Science, 73(4), 312-320.

[4] Hatipoğlu, A., Çelik, Ş., 2012. Diyarbakır İli Karacadağ Havzasında Üretilen Geleneksel Peynirler ve Karşılaşılan Sorunlar. 3.Geleneksel Gidalar Sempozyumu, 10-12 Mayıs, Konya, 8992.

[5] Anonim, 2020. TÜİK (Türkiye İstatistik Kurumu), Hayvancılık İstatistikleri. https://biruni.tuik.gov.tr/medas/?kn=101\&loca le $=\operatorname{tr}($ Erişim tarihi: 01.10.2020).

[6] Fox, P. F., Guinee, T. P., Cogan, T. M., Mcsweeney, P. L. H., 2000. Fundamentals of Cheese Science. Aspen Publishers, Gaithersburg, Maryland, 638s.

[7] Ertaş, N., Doğruer, Y., 2010. Besinlerde Tekstür. Erciyes Üniversitesi Veteriner Fakültesi Dergisi, 7(1), 35-42.

[8] Andronoiu, D.G., Botez, E., Nistor, O.V., Mocanu, G.D., 2015. Ripening process of Cascaval cheese: compositional and textural aspects. Journal of Food Science and Technology, 52(8), 52785284.

[9] Cardello, A.V., Matas, A., Sweeney, J., 1982. The Standard Scales of Texture: Rescalling by Magnitude Estimation. Journal of Food Science, 47, 1738-1742.

[10] Szczesniak, A. S., 1963. Classification of Textural Characteristics. Journal of Food Science, 28(4), 385-389.

[11] Van Vliet, T., 2002. On the Relation Between Texture Perception and Fundamental Mechanical Parameters for Liquids and Time Dependent Solids. Food Quality and Preference, 13, 227-236.

[12] Mcsweeney, P. L. H., Fox, P. F., Lucey, J. A., Jordan, K. N., Cogan, T. M., 1993. Contribution of the Indigenous Microflora to the Maturation of Cheddar Cheese. International Dairy Journal, 3, 613-634.

[13] Özdemir, S., Çelik, Ş., Özdemir C., Sert S., 1998. Diyarbakır'ın Karacadağ Yöresinde Mahalli Olarak Yapılan Örgü Peynirinin Mikrobiyolojik Ve Kimyasal Özellikleri. V. Süt ve Süt Ürünleri Sempozyumu. 21-22 Mayıs, Tekirdağ, 154-166. 
[14] Vural, A., Erkan, M. E., Guran, H. Ş., 2010. The Examination of the Microbiologic Quality in Örgü Cheese (Braided Cheese) Samples. Kafkas Üniversitesi Veteriner Fakültesi Dergisi, 16(Suppl-A), 53-58.

[15] Aksu, H., Colak, H., Vural, A., Erkan, M. E., 1999. Diyarbakır Bölgesinde Üretilen Örgü Peynirlerde Mikrobiyolojik ve Kimyasal Özellikler Üzerine Bir Araştırma. Yüzüncü Yıl Üniversitesi Veteriner Fakültesi Dergisi, 10(1-2), 8-11.

[16] Türkoğlu, H., Ceylan, Z. G., Dayisoylu, K. S., 2003. The Microbiological and Chemical Quality of Örgü Cheese Produced in Turkey. Pakistan Journal of Nutrition, 2(2), 92-94.

[17] Anar, S., Soyutemiz, E., Çetinkaya, F., 2000. Örgü Peynirin Üretim Aşamalarında Görülen Bazı Mikrobiyolojik ve Kimyasal Değişimler. Veteriner Fakültesi Dergisi, 19(1-2), 81-85.

[18] Caridi, A., 2003. Identification and First Characterization of Lactic Acid Bacteria Isolated From Artisanal Ovine Cheese Pecorino del Poro. International Journal of Dairy Technology, 56, 105-110.

[19] Gerasi, E., Litopoulou-Tzanetaki, E., Tzenatakis, N., 2003. Microbiological Study of Manura, a Hard Cheese Made from Raw Ovine Milk in the Greek island Sifnos International Journal of Dairy Technology, 52, 117-122.

[20] Yıldız, N., Bircan, H., 1994. Araştırma ve Deneme Metotları. Atatürk Üniv. Ziraat Fak. Yay. No: 305, Erzurum, 266s.

[21] Koçak, C., 1988. Peynirde Tekstür Oluşumu. Gıda, 13(1), 13-16.

[22] Fedrick, I., 1987. Technology and Economics of the Accelerated Ripening of Cheddar Cheese. Australian Journal of Dairy Technology, 42, 3336.

[23] Mistry, V. V., Kasperson, K. M., 1998. Influence of Salt on the Quality of Reduced Fat Cheddar Cheese. Journal of Dairy Science, 81,1214-1221.

[24] Say, D., 2008. Haşlama Suyunun Tuz Konsantrasyonu ve Depolama Süresinin Kaşar Peynirinin Özellikleri Üzerine Etkileri. Çukurova Üniversitesi Fen Bilimleri Enstitüsü Doktora Tezi, 131s, Adana.

[25] Awad, S., 2006. Texture And Flavour Development in Ras Cheese Made From Raw and Pasteurised Milk. Food Chemistry, 97, 394-400.

[26] Girard, J.P., Culioli, J., Maillard, T., Denoyer, C., Tauraille, C., 1990. Influence of Technological Parameter on the Structure of Batter and the Texture of Frankfurter type Sausages. Meat Science, 27,13-28.
[27] Creamer, L. C., Olson, N. F., 1982. Rheological Evaluation of Maturing Cheddar Cheese. Journal of Food Science, 47(2), 631-646.

[28] Koca, N., 2002. Bazı İkame Maddelerinin Yağı Azaltılmış Taze Kaşar Peynirinin Nitelikleri Üzerine Etkisi. Ege Üniversitesi Fen Bilimleri Enstitüsü, Doktora Tezi, 227s, İzmir.

[29] Yaşar, K., 2007. Farklı Pıhtılaştırıcı Enzim Kullanımının ve Olgunlaşma Süresinin Kaşar Peynirinin Özellikleri Üzerine Etkisi. Çukurova Üniversitesi Fen Bilimleri Enstitüsü, Doktora Tezi, 134s, Adana.

[30] Gobbetti, M., Morea, M., Baruzzi, F. Corbo, M.R., Matarante, A., Considine, T., Di Cagno, R., Guinee, T., Fox, P. F., 2002. Microbiological, Compositional, Biochemical and Textural Characterisation of Caciocavallo Pugliese Cheese during Ripening. International Dairy Journal, 12, 511-523.

[31] Katsiari, M. C., Voutsinas, L. P., Kondyli, E., 2002. Improvement of Sensory Quality of Low-Fat Kefalograviera-type Cheese with Commercial Adjunct Cultures. International Dairy Journal, $12,757-764$.

[32] Fuentes, L., Mateo, J., Quinto, E. J., Caro, I., 2015. Changes in quality of nonaged pasta filata Mexican cheese during refrigerated vacuum storage. Journal of Dairy Science, 98, 2833-2842.

[33] Kaminarides, S., Moschopoulou, E., Karali, F., 2019. Influence of Salting Method on the Chemical and Texture Characteristics of Ovine Halloumi Cheese. Foods, 8, 232.

[34] Maldonado, R. Melendez, B., Arispe, I., Boeneke, C.,Torrico, D., Prinyawiwatkul, W., 2013. Effect of $\mathrm{pH}$ on technological parameters and physicochemical and texture characteristics of the pasta filata cheese Telita. Journal of Dairy Science, 96, 7414-7426.

[35] Yates, M. D., Drake, M. A., 2007. Texture Properties of Gouda Cheese. Journal of Sensory Studies, 22, 493-506

[36] Kesenkaş, H., Dinkçi, N., Seçkin, K., Gürsoy, O., Kınık, Ö., 2012. Physicochemical, Biochemical, Textural and Sensory Properties of Telli Cheese A Traditional Turkish Cheese Made from Cow Milk. Bulgarian Journal of Agricultural Science, 18(5), 763-770.

[37] Fresno, M., Alvarez, S., 2012. Chemical, Textural and Sensorial Changes during the Ripening of Majorero Goat Cheese. International Journal of Dairy Technology, 65(3), 393-400.

[38] Aday, M. S., Caner, C., Karagül-Yüceer, Y., 2010. Instrumental and Sensory Measurements of Ezine Cheese Texture. Akademik Gıda, 8(3), 610. 
[39] Delgado, F. J., Gonzalez-Crespo, J., Cava, R., Ramirez, R., 2011. Proteolysis, Texture and Colour of a Raw Goat Milk Cheese throughout The Maturation. European Food Research and Technology, 233, 483-488.

[40] Patir, B., Ateş, G., Dinçoğlu, A. H., 2001. Geleneksel Yöntemle Üretilen Tulum Peynirinin Olgunlaşması Sırasında Meydana Gelen Mikrobiyolojik ve Kimyasal Değişimler Üzerine Araştırmalar. Fırat Üniversitesi Sağlık Bilimleri Dergisi, 15(1), 1-8.

[41] Ortigosa, M., Arizcun, C., Irigoyen, A. Oneca, M., Torre, P., 2006. Effect of Lactobacillus Adjunct Cultures on the Microbiological and Physicochemical Characteristics of Roncal-type Ewes'-Milk Cheese. Food Microbiology. 23, 591598.

[42] Öner, Z. Karahan, A. G., Aloğlu, H., 2006. Changes in the Microbiological and Chemical Characteristics of an Artisanal Turkish White Cheese During Ripening. LWT, 39, 449-454.

[43] Calvo, M. V., Castillo, I., Diaz-Barcos, V., Requena, T., Fontecha, J., 2007. Effect of a Hygienized Rennet and a Defined Strain Starter on Proteolysis, Texture and Sensory Properties of Semi-Hard Goat Cheese. Food Chemistry, 102, 917-924.

[44] Güven, M., Konar, A., 1984. İnek Sütlerinden Üretilen ve Farklı Ambalajlarda Olgunlaştırılan Tulum Peynirlerinin Mikrobiyolojik Özellikleri. Gida, 19(3), 179-185.

[45] Marino, M., Maifreni, M., Rondinini, G., 2003. Microbiological Characterization of Artisanal Montasio Cheese, Analysis of its Indigenous Lactic Acid Bacteria. FEMS Microbiology Letters, $229,133-140$.

[46] Uysal, Ş., 2008. Dil Peyniri Üretiminde Doğal Termofilik Peyniraltı Suyu (PAS) Kültürünün Kullanım Olanağının Araştırılması, Harran Üniversitesi Fen Bilimleri Enstitüsü, Yüksek Lisans Tezi, 91s, Șanlıurfa.

[47] Gökovalı, T., 1980. Salamuralı Tulum Peynirinin Olgunlaşması Sirasında Meydana Gelen Mikrobiyolojik Değişiklikler Üzerinde Araştırma. İhtisas Tezi, 75s, İzmir.

[48] Ferrazza, R. E., Fresno, J. M., Ribeiro, J. I., Tornadijo, M. E., Mansur Furtado, M., 2004. Changes in the Microbial Flora of Zamorano Cheese (P.D.O.) by Accelarated Ripening Process. Food Research International, 37, 149-155.
[49] Anonim, 2016. TS 3002 No' lu Dil Peyniri Standardı. Türk Standartları Enstitüsü, 9s., Ankara.

[50] Albenzio, M., Corbo, M. R., Rehman, S. U., Fox, P. F., De Angelis, M., Corsetti, A., Sevi, A., Gobbetti, M., 2001. Microbiological and Biochemical Chacacteristics of Canestrato Pugliese Cheese Made from Raw Milk, Pasteurized Milk or by Heatig Curd in Hot Whey. International Journal of Food Microbiology, 67, 35-48.

[51] Cabezas, L., Sánchez, I., Poveda, J. M., Seseña, S., Palop, M. L., 2007. Comparison of Microflora, Chemical and Sensory Charactaristics of Artisanal Manchego Cheeses from Two Dairies. Food Control, 18, 11-17.

[52] Tham, W. A., Hajdu, L. J., Danielsson-Tham, M. L. V., 1990. Bacteriological Quality of on-farm Manufactured Goat Cheese. Epidemiology\& Infection, 104, 87-100.

[53] Zárate, V., Belda, F., Pérez, C., Cardell, E., 1997. Changes in the Microbial Flora of Tenerife Goats' Milk Cheese During Ripening. International Dairy Journal, 7, 635-641.

[54] Çelik, Ş., Özdemir, C., Özdemir, S., 2001. Production Techniques and Some Properties of Traditional Lavas cheese. Journal of Biological Sciences, 1 (7), 603-605.

[55] Manolopoulou, E. Sarantinopoulos, P., Zoiidou, E., Aktypis, A. Moschopoulou, E., Kandarakis, I. G., Anifantakis E. M., 2003. Evolution of Microbial Populations During Traditional Feta Cheese Manufactura and Ripening. International Journal of Food Microbiology, 82(2), 153-161.

[56] Aran, N., Eke, D., Alperden, İ., 1986. Yarı Sert Karakterdeki Türk Peynirlerinde Küf Florası. Ege Üniversitesi Mühendislik Fakültesi Dergisi, 4(2), 1-10.

[57] Anonim, 2015. Türk Gıda Kodeksi Peynir Tebliği (Tebliğ No: 2015/6). https://www.resmigazete.gov.tr/eskiler/2015/ 02/20150208-16.htm (Erişim Tarihi: 03.01.2020).

[58] Anonim, 2009. Türk Gıda Kodeksi Fermente Süt Ürünleri Tebliği (Tebliğ No: 2009/25). https://www.resmigazete.gov.tr/eskiler/2009/ 02/20090216-8.htm (Erişim Tarihi: 30.08.2020). 